Volume 3 Nomor 1, Februari 2018, Halaman 65-76

\title{
PENGARUH PEMBELAJARAN BERMUATAN KARAKTER KREATIF TERHADAP KEMAMPUAN KONEKSI MATEMATIK
}

\author{
THE INFLUENCE OF LEARNING CHARGED CREATIVE \\ CHARACTER TO MATHEMATICAL CONNECTION ABILITY
}

\author{
Denni Ismunandar \\ Universitas Wiralodra, Jln. Ir. H. Djuanda KM.3 Singaraja Indramayu 45213, \\ denniismunandar@gmail.com
}

\begin{abstract}
ABSTRAK
Tujuan dari penelitian ini adalah mengetahui pengaruh karakter kreatif terhadap kemampuan koneksi matematik siswa kelas XI IPS. Informasi awal dari beberapa guru mata pelajaran matematika di SMA tempat peneliti melakukan penelitian adalah karakter kreatif perlu dimiliki oleh siswa untuk menyelesaikan permasalahan dalam bentuk soal cerita atau soal dalam kehidupan sehari - hari; kurangnya latihan siswa sehingga mengakibatkan siswa cepat lupa dengan rumus yang telah diberikan; guru mata pelajaran matematika sepakat bahwa materi komposisi fungsi merupakan salah satu materi yang dipandang sulit oleh siswa. Penelitian ini dilaksanakan di SMAN 1 Indramayu tahun ajaran 2013/2014. Pemilihan sampel dilakukan dengan random sampling dan terpilih kelas XI IPS 2 sebagai kelas observasi. Metode pengumpulan data menggunakan eksperimen dan observasi. Hasil penelitian adalah karakter kreatif berpengaruh terhadap kemampuan koneksi matematik sebesar 83,4\%. Hal ini terlihat dari sig. (2-tailed) menujukkan nilai sig $=0.000=0 \%<\alpha=0,05$, artinya terdapat korelasi antara karakter kreatif dan kemampuan koneksi matematik yang tidak lemah dan Pearson Correlation menunjukkan nilai $r=0.834$, artinya terdapat pengaruh yang kuat sebesar $83,4 \%$.
\end{abstract}

Kata kunci: Karakter, Kreatif, Koneksi, Matematik

\begin{abstract}
Purpose of this research is know influence creative character to connection mathematics ability of student in grade XI IPS. Initial information from the mathematics teacher in Senior High School place of researchers do research is the student need creative character to fimish of contextual problem; less of exercise make the student quickly forget of formula has been given; the teacher agreed that composition of fungtion is one of material is difficult. This research to held in SMAN 1 Indramayu academic years 2013/2014. Selection of sample with sampling random and selected XI IPS 2 class as observation class. The methods in this research is experiment and observation. The result of this research is creative character influence to mathematics ability as $83,4 \%$. This matter from look at sig. (2-tailed) show that sig $=0.000=0 \%<\alpha=0,05$, its mean there is strong correlation betwen creative character with connection mathematics ability and Pearson Correlation show that value of $r=0.834$, its mean there is strong influence betwen creative character with connection mathematics ability.
\end{abstract}

Keywords: Creative, Character, Connection, Mathematics 
How to Cite: Ismunandar, D. (2018). Pengaruh Pembelajaran Bermuatan Karakter Kreatif Terhadap Kemampuan Koneksi Matematik. Mathline: Jurnal Matematika dan Pendidikan Matematika, Vol.3, No.1, 65-76.

\section{PENDAHULUAN}

Pemerintah Indonesia beberapa tahun yang lalu pada dunia pendidikan menggalakkan pendidikan berkarakter. Pendidikan karakter adalah usaha menanamkan kebiasaan-kebiasaan yang baik (habituation) sehingga peserta didik mampu bersikap dan bertindak berdasarkan nilai-nilai yang telah menjadi kepribadiannya (Kemendiknas, 2011). Pendidikan karakter yang diterima di sekolah dan di lingkungan keluarga akan menciptakan siswa yang mempunyai kepribadian yang baik dan unggul.

Hal ini senada dengan pendapat Harun (2013) bahwa pendidikan karakter memiliki makna lebih tinggi dari pendidikan moral karena pendidikan karakter tidak hanya berkaitan dengan benar atau salah, namun bagaimana menanamkan kebiasaan yang baik dalam kehidupan sehari - hari, sehingga anak memiliki kesadaran dan pemahaman yang tinggi serta kepedulian dan komitmen untuk berbuat baik dalam kehidupan sehari-hari. Suyitno (2012) berpendapat bahwa sebagai agen perubahan, pendidik diharapkan mampu menanamkan ciri-ciri, sifat, dan watak serta jiwa mandiri, tanggung jawab, dan cakap dalam kehidupan peserta didiknya.

Hampir setiap sekolah di Indonesia, pendidikan karakter disisipkan pada setiap mata pelajaran melalui rencana pelaksanaan pengajaran (RPP) yang disusun oleh masing masing guru. Pada saat mengajar, guru yang telah membuat RPP akan melakukan kegiatan belajar mengajar sesuai dengan RPP, sisipan pendidikan karakter yang dipilih oleh guru dikembangkan dalam pembelajaran dikelas. Beberapa karakter yang tercantum dalam permendiknas nomor 23 tahun 2006 terkait dengan standar lulusan satuan pendidikan tingkat SMA adalah mempunyai karakter jujur, percaya diri, bertanggung jawab, berfikir logis, kritis, kreatif, dan inovatif. Standar lulusan ini bertujuan supaya ketika siswa lulus dari sekolah memiliki beberapa karakter tersebut. Pada pelajaran matematika, karakter yang sering disisipkan dalam pembelajaran adalah jujur, berfikir kritis, mandiri, berfikir logis, dan kreatif.

Penelitian dilakukan oleh peneliti yaitu pada salah satu SMA di Kabupaten Indramayu tahun pelajaran 2013/2014. Peneliti mendapatkan kesempatan untuk melakukan penelitian pada sekolah yang melaksanakan dua kurikulum. Yaitu kurikulum KTSP dan kurikulum 2013. Kurikulum KTSP dilaksanakan pada tingkat XI dan XII, sedangkan 
kurikulum 2013 dilaksanakan pada tingkat X. Sebelum penelitian dilaksanakan, peneliti mengumpulkan informasi dari beberapa guru mata pelajaran matematika di SMA tersebut. Hasil pengumpulan informasi tersebut adalah karakter kreatif perlu dimiliki oleh siswa untuk menyelesaikan permasalahan dalam bentuk soal cerita atau soal dalam kehidupan sehari-hari; kurangnya latihan siswa sehingga mengakibatkan siswa cepat lupa dengan rumus yang telah diberikan; guru mata pelajaran matematika sepakat bahwa materi komposisi fungsi merupakan salah satu materi yang dipandang sulit oleh siswa. Penelitian yang dilakukan hanya terbatas pada tingkat XI jurusan IPS karena peneliti hanya diperbolehkan oleh pihak sekolah pada tingkatan tersebut.

Pada penelitian ini, peneliti melakukan pengamatan pada karakter kreatif siswa, karena karakter kreatif adalah salah satu standar lulusan pada SMA tempat peneliti melakukan penelitian. Menurut Nur'aeni (2008), "kreatif adalah suatu kondisi, sikap atau keadaan yang sangat khusus sifatnya dan hampir tak mungkin dirumuskan secara tuntas”. Almasitoh (2013) berpendapat bahwa Kreativitas merupakan suatu proses berpikir yang lancar, lentur, dan orisinal dalam menciptakan suatu gagasan yang bersifat unik, berbeda, orisinal, baru, indah, efisien, dan bermakna, serta membawa seseorang berusaha menemukan metode dan cara baru di dalam memecahkan suatu masalah.

Beberapa karakteristik kepribadian individu yang kreatif menurut Munandar yang dikutip oleh Lestari (2006) adalah (1) mandiri dalam sikap dan perilaku sosial, (2) keterbukaan terhadap rangsangan dari luar, (3) memiliki minat yang luas dan rasa ingin tahu, (4) kepercayaan terhadap diri sendiri, (5) memperhatikan kekuatan firasat dan ketidaksadaran, (6) keteguhan dan ketabahan hati dalam menghadapi kesulitan, (7) Kemampuan menggunakan kekuatan imajinasi untuk menciptakan ide-ide baru, (8) motivasi intrinsik dalam bekerja dan berkarya, (9) menggunakan kekuatan perasaan termasuk firasat dan ketidaksadaran dalam memecahkan masalah, (10) kelancaran, kelenturan, dan keaslian dalam berpikir untuk menemukan alternatif dalam melihat masalah kehidupan, (11) ketajaman dan kepekaan dalam melihat masalah kehidupan, (12) kemampuan berpikir analisis dan sintetis dalam memecahkan masalah, (13) memiliki pengamatan yang tajam terhadap fakta dan realita kehidupan, (14) memiliki sensitivitas terhadap keindahan dan menggunakan sebagai kekuatan untuk berpikir baru dan memecahkan masalah.

Batey (2012) berpendapat bahwa kreatif adalah produk atau hasil baru yang original dari seseorang yang didominasi oleh penciptaan dari suatu kejadian. Untuk meningkatkan kreatifitas siswa dalam matematika, menurut Brunkalla (2009) siswa harus 
mempunyai kreatifitas abstraksi, kreatifitas koneksi dan kreatifitas meneliti. Kreatifitas abstraksi yaitu kemampuan siswa dalam mengubah permasalahan di dunia nyata kedalam model matematika. Kreatifitas koneksi yaitu kemampuan siswa dalam menyelesaikan masalah baru terkait dengan permasalahan antar topik matematika, terkait dengan bidang studi lain dan terkait dengan permasalahan sehari-hari menggunakan alat atau rumus matematika yang telah diperoleh siswa. Kreatifitas meneliti yaitu menemukan konsep dari materi yang dipelajari dan konsep tersebut dapat dipahami oleh siswa lain.

Berdasarkan informasi yang didapat dari guru, bahwa siswa masih kesulitan untuk menyelesaikan permasalahan dalam bentuk soal cerita atau soal dalam kehidupan sehari hari. Peneliti mengasumsikan bahwa siswa memerlukan kemampuan koneksi matematik untuk memecahkan masalah terkait dengan permasalahan dalam kehidupan sehari - hari. Menurut NCTM (2000), terdapat lima standar proses dalam pembelajaran matematika, yaitu: 1) belajar untuk memecahkan masalah (mathematical problem solving); 2) belajar untuk bernalar dan bukti (mathematical reasoning and proof); 3) belajar untuk berkomunikasi (mathematical communication); 4) belajar untuk mengaitkan ide (mathematical connections); dan 5) belajar untuk mempresentasikan (mathematics representation). Dalam penelitian ini, peneliti mengambil salah satu dari standar proses yang telah ditetapkan oleh NCTM, yaitu belajar untuk mengaitkan ide (mathematical connections).

Menurut Harnish yang dikutip oleh Azizah, dkk. (2012), terdapat tiga macam koneksi yang harus dikembangkan, yaitu: (1) data connection, (2) language connection, and (3) life connection. Menurut Ramdani (2012), kemampuan koneksi matematis meliputi: (1) mencari dan memahami hubungan berbagai representasi konsep bidang studi lain atau kehidupan sehari-hari; (2) memahami representasi ekuivalen konsep atau prosedur yang sama; (3) mencari koneksi satu prosedur ke prosedur lain dalam representasi yang ekuivalen; dan (4) menggunakan koneksi antar topik matematika, dan antara topik matematika dengan topik lain. Pembelajaran yang dilakukan di sekolah selama ini masih menggunakan pembelajaran yang ekspositori, oleh karena itu, perlu suatu tindakan untuk mempermudah siswa mempunyai kemampuan koneksi matematik.

Menurut Ketterin-Geller, et al. (2008) untuk mempermudah siswa mempunyai kemampuan koneksi matematika, informasi tentang kemampuan siswa dibutuhkan oleh seorang guru, yaitu pemantauan dan screening. Screening yang dimaksud adalah mengidentifikasi siswa berdasarkan data dari guru, administrasi sekolah, informasi dari siswa lain dan informasi dari orang tua siswa untuk dievaluasi kemajuan siswa tertentu 
pada materi sebelumnya. Sreening merupakan langkah mengidentifikasi siswa. Siswa diidentifikasikan untuk mengetahui resiko untuk gagal atau siswa berada di jalur yang tepat. Pada umumnya siswa di identifikasikan menjadi tiga kategori berdasarkan resikonya yaitu (a) siswa yang tidak beresiko, yaitu siswa yang berada di jalur yang tepat, sehingga dapat memahami konsep yang diberikan, (b) siswa yang beresiko rendah, yaitu siswa berada didaerah yang kritis, artinya siswa tersebut nilainya masih kurang namun masih dimungkinkan adanya tambahan pelajaran, sehingga siswa dapat memahami konsep yang diberikan, (c) siswa beresiko, yaitu siswa yang berada jauh diluar jalur, siswa tersebut nilainya kurang memuaskan dan perlu adanya pendampingan dari guru sebagai fasilitator untuk membawa siswa tersebut ke jalur yang tepat. Selain dari guru, faktor terbesar yang mempengaruhi siswa beresiko yaitu pengaruh dari siswa lain atau pengaruh dari teman di lingkungannya. Tujuan dari penelitian ini adalah untuk mengetahui korelasi atau hubungan antara karakter kreatif siswa dengan kemampuan koneksi matematik siswa.

\section{METODE PENELITIAN}

Penelitian ini dilaksanakan di SMAN 1 Indramayu yang beralamat di Jln. Soekarno Hatta No. 2 Kelurahan Pekandangan Kecamatan Indramayu Kabupaten Indramayu. Penelitian dilaksanakan pada semester genap tahun ajaran 2013/2014. Peneliti dan guru pengajar kelas XI IPS sepakat untuk mengambil materi komposisi fungsi untuk dijadikan materi pada penelitian ini.

Menurut Sugiyono (2013), populasi adalah wilayah generalisasi yang terdiri atas: obyek/ subyek yang mempunyai kualitas dan karakteristik tertentu yang ditetapkan oleh peneliti untuk dipelajari dan kemudian ditarik kesimpulannya. Populasi penelitian ini adalah siswa kelas XI IPS yang berjumlah 132 siswa yang terdiri atas kelas XI IPS 1 sejumlah 33 siswa, kelas XI IPS 2 sejumlah 33 siswa, kelas XI IPS 3 berjumlah 32 siswa, dan kelas XI IPS 4 berjumlah 32 siswa.

Sugiyono (2013) berpendapat bahwa sampel adalah bagian dari jumlah dan karakteristik yang dimiliki oleh populasi tersebut. Pengambilan sampel pada penelitian ini menggunakan random sampling. Peneliti menggunakan teknik ini karena informasi yang didapat dari guru pengajar keempat kelas tersebut adalah keempat kelas tersebut mempunyai kemampuan kognitif yang hampir sama. Setiap kelas terdiri dari siswa yang mempunyai kemampuan kognitif tinggi sedang dan rendah, sehingga setiap kelas dapat dikatakan kemampuan kognitif siswa heterogen. 
Pengambilan sampel dilakukan dengan kocokan, seperti pada acara arisan. Setiap kertas terdiri dari satu kelas, karena peneliti hanya mengambil satu kelas untuk diamati karakter kreatif siswanya. Hasil pengambilan sampel tersebut adalah kelas XI IPS 2. Dengan demikian pengamatan karakter kreatif dilakukan pada siswa kelas XI IPS 2 dengan mengacu kemampuan koneksi matematis siswa. Metode yang digunakan dalam penelitian ini adalah metode eksperimen dan metode observasi. Tujuan dari metode eksperimen pada penelitian ini hanya mengambil hasil kemampuan koneksi matematik siswa pada post test. Soal-soal yang diberikan pada post test merupakan soal-soal yang disusun sesuai dengan indikator kemampuan koneksi matematik. Menurut Arikunto (2010), metode observasi adalah suatu usaha sadar untuk mengumpulkan data yang dilakukan secara sistematis dengan prosedur yang standar. Metode observasi dilakukan pada siswa pada setiap pertemuan untuk diamati karakter kreatif dari siswa.

Pengumpulan data dilakukan sebanyak empat kali yang terdiri dari tiga kali pengamatan karakter kreatif siswa dan satu kali pengambilan tes kemampuan koneksi matematik pada akhir pertemuan. Desain penelitian pada penelitian ini adalah sebagai berikut:

$\mathrm{X} \longrightarrow \mathrm{Y}$ (Sugiyono, 2013)

Keterangan:

$\mathrm{X}$ : karakter kreatif siswa

Y: kemampuan koneksi matematik siswa

Analisis data pada penelitian ini menggunakan software SPSS untuk menguji normalitas, homogenitas dan uji korelasi antara karakter kreatif dengan kemampuan koneksi matematik siswa.

\section{HASIL DAN PEMBAHASAN}

Berikut ini ditampilkan hasil perhitungan tes kemampuan koneksi matematik siswa materi komposisi fungsi setelah pembelajaran dilaksanakan dan hasil observasi karakter kreatif siswa kelas XI IPS 2. 


\section{Tabel 1 Hasil Perhitungan Nilai siswa Kemampuan Koneksi Matematik Siswa}

\begin{tabular}{lr}
\hline \multicolumn{2}{c}{ Kelas XI IPS 2 } \\
\hline Jumlah Siswa & 33 \\
Rata - rata & 57.7273 \\
Simpangan Baku & 11.30617 \\
Varian & 127.830 \\
Minimum & 37.00 \\
Maximum & 76.00 \\
Sum & 1905.00 \\
\hline
\end{tabular}

Berdasarkan tabel 1 terlihat bahwa rata-rata kemampuan koneksi matematik siswa kelas XI IPS 2 adalah 57,72 dengan nilai minimum 37 dan maksimum 76. Simpangan baku sebesar 11,3 dan varian sebesar 127,83 artinya dengan varian tersebut, sebaran nilai kelas XI IPS 2 cukup besar. Namun normal atau tidak hasil Kemampuan Koneksi Matematik siswa perlu dilakukan uji normalitas.

\begin{tabular}{lr} 
Tabel 2 Hasil Pengamatan Karakter Kreatif \\
\hline \multicolumn{2}{c}{ KELAS XI IPS 2 } \\
\hline Jumlah Siswa & 33 \\
Mean & 63.94 \\
Median & 61.00 \\
Std. Deviation & 14.686 \\
Variance & 215.684 \\
Minimum & 32 \\
Maximum & 91 \\
Sum & 2110
\end{tabular}

Berdasarkan tabel 2 terlihat bahwa rata-rata karakter kreatif siswa adalah 63,94 dengan nilai minimum 32 dan nilai maksimum 91. Simpangan baku sebesar 14,686 dan varian sebesar 215, 684 artinya dengan varian tersebut, sebaran karakter kreatif siswa kelas XI IPS 2 cukup besar. Perlu digaris bawahi bahwa karakter kreatif adalah penilaian sikap yang diamati oleh peneliti selama tiga kali pertemuan dan bukan merupakan kemampuan berfikir kreatif. Langkah selanjutnya adalah menguji normalitas dari kemampuan koneksi matematik siswa. Uji normalitas kemampuan koneksi matematik siswa menggunakan software SPSS dan didapat output pada tabel 3. 
Pengaruh Pembelajaran Bermuatan Karakter Kreatif Terhadap Kemampuan Koneksi Matematik

Tabel 3 Tes Normalitas

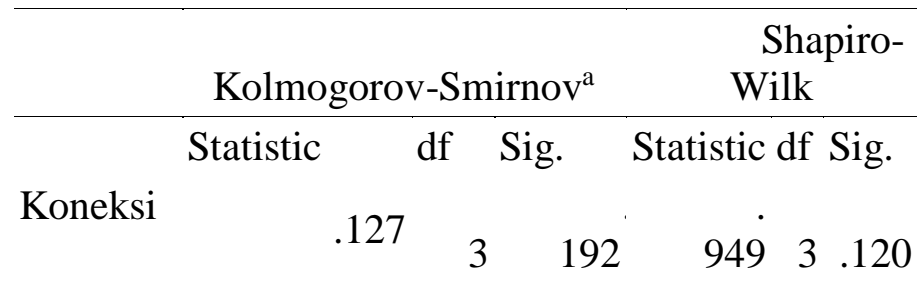

a. Lilliefors Significance

\section{Correction}

Tabel 3 diatas terdapat dua Uji, yaitu uji menggunakan Kolmogorov-Smirnov dan uji menggunakan Shapioro-Wilk. Karena jumlah data kurang dari 50, maka uji normalitas menggunakan Shapioro-Wilk. Hasil uji normalitas dengan analisis Liliefors pada taraf signifikan $\alpha=0,05$ menunjukkan data berdistribusi normal. Hal ini terlihat pada sig = $0.120>\alpha=0,05$. Arti dari data berdistribusi normal adalah data hasil koneksi matematik siswa kelas XI IPS 2 mengumpul di tengah, yaitu pada nilai 50 sampai dengan 60 . Untuk memperkuat pendapat bahwa data berdistribusi normal, diberikan box plot sebagai berikut.

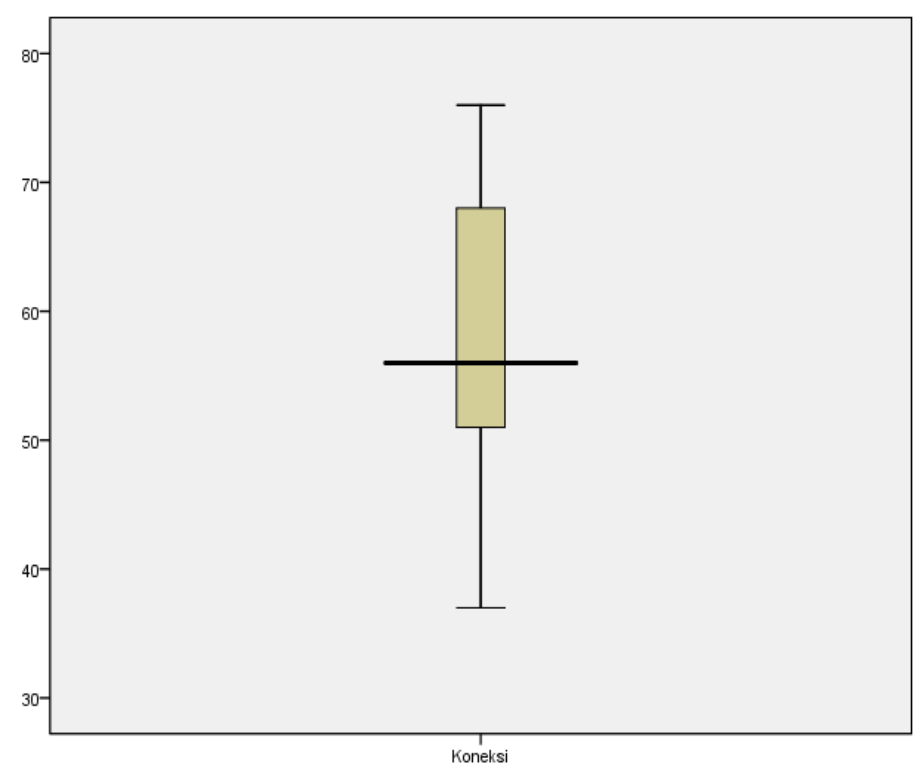

Gambar 1 Box Plot Normalitas Data

Berdasarkan gambar 1 garis normalitas masih berkisar di daerah tengah, sehingga dapat dikatakan bahwa data berdistribusi normal. Selanjutnya akan dilakukan uji homogenitas untuk mengetahui hasi kemampuan koneksi matematik homogen atau tidak. 
Tabel 4 Uji Homogenitas

\begin{tabular}{|c|c|c|}
\hline \multicolumn{3}{|l|}{ Koneksi } \\
\hline \multirow[t]{2}{*}{$\mathrm{N}$} & Valid & \\
\hline & Missing & \\
\hline \multicolumn{3}{|l|}{ Kurtosis } \\
\hline & & .943 \\
\hline \multicolumn{3}{|c|}{ Std. Error of Kurtosis } \\
\hline \multirow{2}{*}{\multicolumn{3}{|c|}{ Minimum }} \\
\hline & & \\
\hline \multicolumn{3}{|l|}{ Maximum } \\
\hline \multirow[t]{6}{*}{ Percentiles } & 2 & \\
\hline & 5 & 0.50 \\
\hline & 5 & \\
\hline & 0 & 6.00 \\
\hline & 7 & \\
\hline & 5 & 8.50 \\
\hline
\end{tabular}

Berdasarkan tabel 4 diatas, dapat dideskripsikan sebagai berikut. Nilai kurtosis pada kelas XI IPS 2 menunjukkan nilai -0.943. Artinya data cenderung tumpul dan nilai tidak jauh dari nol, sehingga dapat dikatakan kelas tersebut cenderung homogen. Hal ini dapat dibuktikan dengan gambar 2.

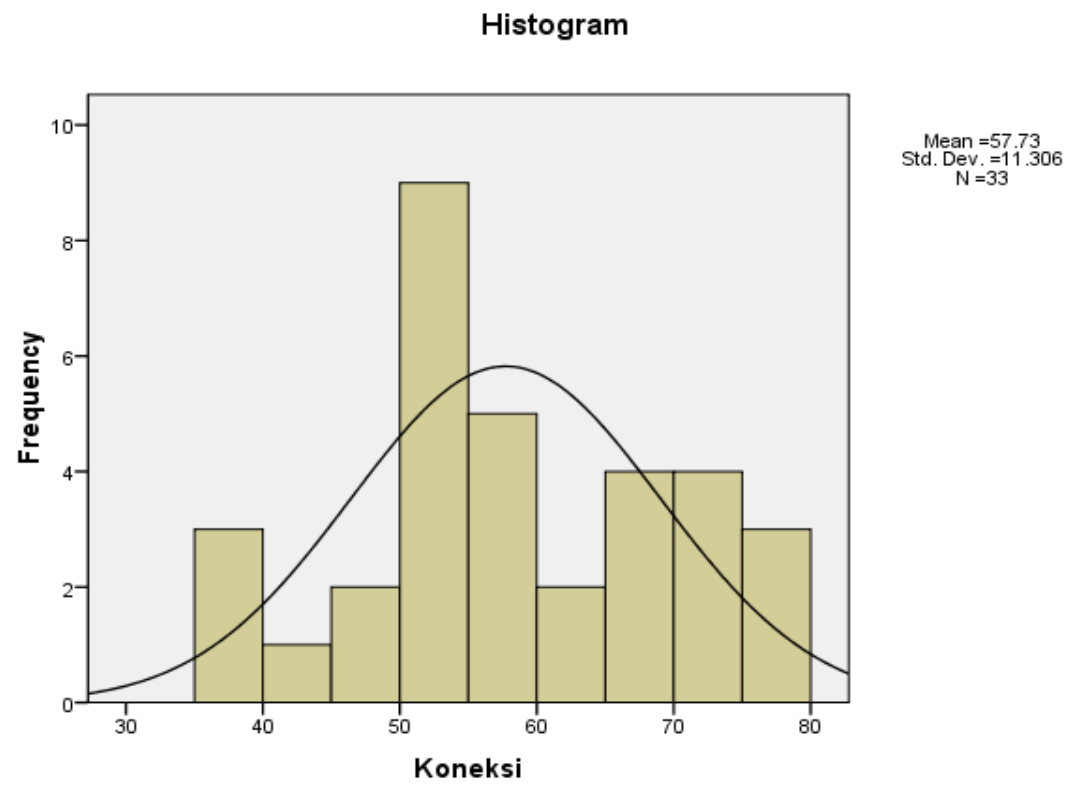

Gambar 2 Histogram Kemampuan Koneksi Matematik 
Gambar 2 menunjukkan bahwa data cenderung tumpul dan mengelompok di tengah, sehingga dapat disimpulkan kemampuan koneksi matematik siswa kelas XI IPS 2 homogen. Dengan membaca tabel 4 dan gambar 2 dapat disimpulkan bahwa data benarbenar homogen. Selanjutnya, dilakukan uji korelasi untuk menguji seberapa kuat hubungan antara karakter kreatif dengan kemampuan koneksi matematik siswa.

Menurut Sukestiyarno (2012), Koefisien korelasi adalah ukuran seberapa kuat hubungan antara dua variabel atau lebih. Uji Untuk melihat korelasi dan pemaknaan besar nilai korelasi, dapat dilihat dari plot dan uji korelasi. Artinya, sebelum menggunakan uji korelasi, alangkah lebih baik melihat terlebih dahulu plot korelasi data. Jika plot menunjukkan kecenderungan naik dari kiri ke kanan maka dapat dikatakan terdapat korelasi antara karakter kreatif terhadap kemampuan koneksi matematik. Sebaliknya, jika plot menunujkkan kecenderungan menurun dari kanan ke kiri maka dapat dikatakan korelasi lemah antara karakter kreatif terhadap kemampuan koneksi matematik. Berikut diberikan gambar 3 mengenai plot korelasi data.

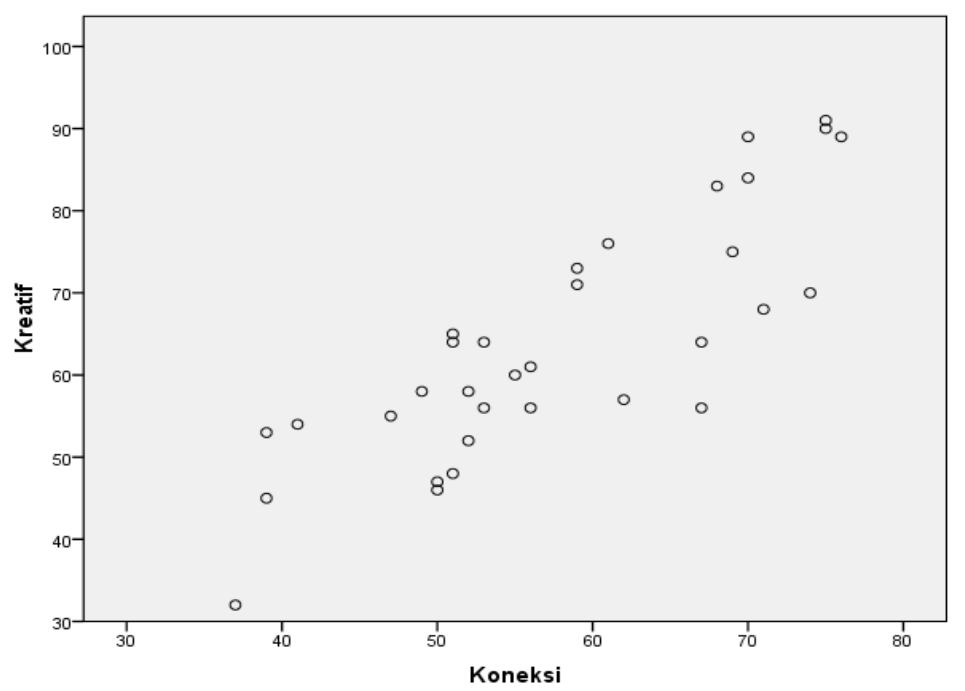

\section{Gambar 3 Plot Antara Karakter Kreatif dengan Kemampuan Koneksi Matematik}

Pada gambar 3, terlihat bahwa plot cenderung naik, artinya terdapat korelasi atau hubungan kuat yang positif antara karakter kreatif dengan kemampuan koneksi matematik. Walaupun data agak sedikit menyebar, namun kecenderungan untuk naik dapat terlihat dengan jelas dari kiri ke kanan, dengan demikian terdapat hubungan yang kuat antara karakter kreatif dengan kemampuan koneksi matematik. Untuk kebermaknaan besar nilai korelasi, dilakukan uji korelasi. 
Tabel 5 Korelasi

\begin{tabular}{llrr}
\hline & & Kreatif & Koneksi \\
\hline Kreatif & Pearson Correlation & 1 & $.834^{* *}$ \\
& Sig. (2-tailed) & & .000 \\
& $\mathrm{~N}$ & 33 & 33 \\
Koneksi & Pearson Correlation & $.834^{* *}$ & 1 \\
& Sig. (2-tailed) & .000 & \\
& $\mathrm{~N}$ & 33 & 33 \\
**. Correlation is significant at the 0.01 level (2-tailed).
\end{tabular}

Berdasarkan tabel 5 diatas, sig. (2-tailed) menujukkan t nilai sig $=0.000=0 \%<$ $\alpha=0,05$, artinya terdapat korelasi antara karakter kreatif dan kemampuan koneksi matematik yang tidak lemah. Pada tabel 5, Pearson Correlation menunjukkan nilai $r=0.834$, artinya terdapat hubungan yang kuat sebesar $83,4 \%$. Hal ini menunjukkan bahwa karakter kreatif berpengaruh terhadap kemampuan koneksi matematik sebesar $83,4 \%$.

Supandi, dkk (2013) dalam penelitiannya menyimpulkan bahwa karakter disiplin, tanggung jawab dan kreativ berpengaruh positif terhadap hasil belajar mahasiswa. Perangkat pembelajaran yang dipakai memberikan kesempatan kepada mahasiswa untuk berfikir terbuka dengan mengerjakan soal-soal latihan secara kreatif, diantaranya keaslian dan keluawesan dalam menjawab soal. Juhartutik (2011) berpendapat bahwa karakter kreatif dapat menghasilkan ide-ide peserta didik melakukan eksplorasi dan menunjukkan kemampuan siswa dalam diskusi. Pada penelitian yang dilakukan oleh Juhartutik dapat mengembangkan kreatif peserta didik serta membangkitkan sisi afektif siswa. Brunkalla (2009) berpendapat bahwa siswa yang mempunyai karakter kreatif mempunyai langkah yang berbeda atau proses untuk menentukan solusi yang berbeda yang berkaitan dengan permasalahan kehidupan sehari-hari. Pendapat para peneliti di atas senada dengan hasil penelitian ini, yaitu karakter kreatif siswa dapat berpengaruh terhadap kemampuan koneksi matematik siswa.

\section{KESIMPULAN}

Kesimpulan berdasarkan penelitian yang telah dilakukan dan hasil analisis data menggunakan software SPSS adalah terdapat pengaruh karakter kreatif terhadap kemampuan koneksi matematik sebesar $83,4 \%$. Saran peneliti kepada guru pengajar kelas 
XI IPS, karakter kreatif siswa dapat berpengaruh terhadap kemampuan koneksi matematik siswa maka silahkan kembangkan soal - soal kemampuan koneksi matematik siswa.

\section{DAFTAR PUSTAKA}

Almasitoh, U. H. (2013). Kepribadian Individu Kreatif: Afiliatif \& Asertif. Magistra, No.83 Th.XXV, 1-10.

Arikunto, S. (2010). Prosedur Penelitian Suatu Pendekatan Praktik. Jakarta. Rineka Cipta.

Azizah, L., Mariani, S., \& Rochmad. (2012). Pengembangan Perangkat Pembelajaran Model CORE bernuansa konstruktivisme untuk meningkatkan Kemampuan Koneksi Matematis. Unnes Journal of Mathematics Education Research, Vol. 2(1), 100-105.

Batey, M. (2012). The Measurement of Creativity: From Definitional Consensus to the Introduction of a New Heuristic Framework. Creativity Research Journal, Vol.24(1), 55-65.

Brunkalla, K. (2009). How To Increase Mathematical Creativity-An Experiment. The Montana Mathematics Enthusiast, Vol. 6, nos 1\&2, 257 - 266.

Harun, C. Z. (2013). Managemen Pendidikan Karakter. Jurnal Pendidikan Karakter, Vol.III (3), 302-308.

Juhartutik. (2011). Menjadi Guru Matematika Kreatif dan Berwawasan Pendidikan Karakter. Kreano, Vol. 2(1), 13-26.

Kemendiknas. (2011). Panduan Pelaksanaan Pendidikan Karakter. Jakarta: Kemendiknas.

Ketterin-Geller, L. R., Chard, D. J., \& Fien, H. (2008). Making Connections in Mathematics Conceptual Mathematics Intervention for Low-Performing Student (Remedial and Special Education). Hammill Institute on Disabilities and Sage Publications, 29-33.

Lestari, B. (2006). Upaya Orang Tua Dalam Pengembangan Kreativitas Anak. Jurnal Ekonomi \& Pendidikan, Vol.3(1), 17-24.

NCTM. (2000). Principles and Standarts for School Mathematics. Reston, VA: NCTM.

Nur'aeni. (2008). Ada Apa Dengan Kreatifitas. ISLAMADINA, Vol.VII(3), 74-84.

Ramdani, Y. (2012). Pengembangan Instrumen dan Bahan ajar untuk meningkatkan kemampuan komunikasi, Penalaran, dan Koneksi Matematis dalam konsep Integral. Jurnal Penelitian Pendidikan, Vol.13(1), 44-52.

Sugiyono. (2013). Model Penelitian Pendidikan Pendekatan Kuantitatif, Kualitatif, dan $R \& D$. Bandung: Alfabeta.

Sukestiyarno. (2012). Olah Data Penelitian Berbantua SPSS. Semarang: UNNES.

Supandi, Kusumaningsih, W., Ariyanto, L., Nurlaelah, E., \& Turmudi. (2013). Pembelajaran Kalkulus Berbasis E-Learning Untuk menumbuhkan Kreativitas dan Karakter Mahasiswa. Kreano, Vol.4(2), 126-130.

Suyitno, I. (2012). Pengembangan pendidikan karakter dan Budaya Bangsa Berwawasan Kearifan Lokal. Jurnal Pendidikan Karakter, Vol.II(1), 1-13. 